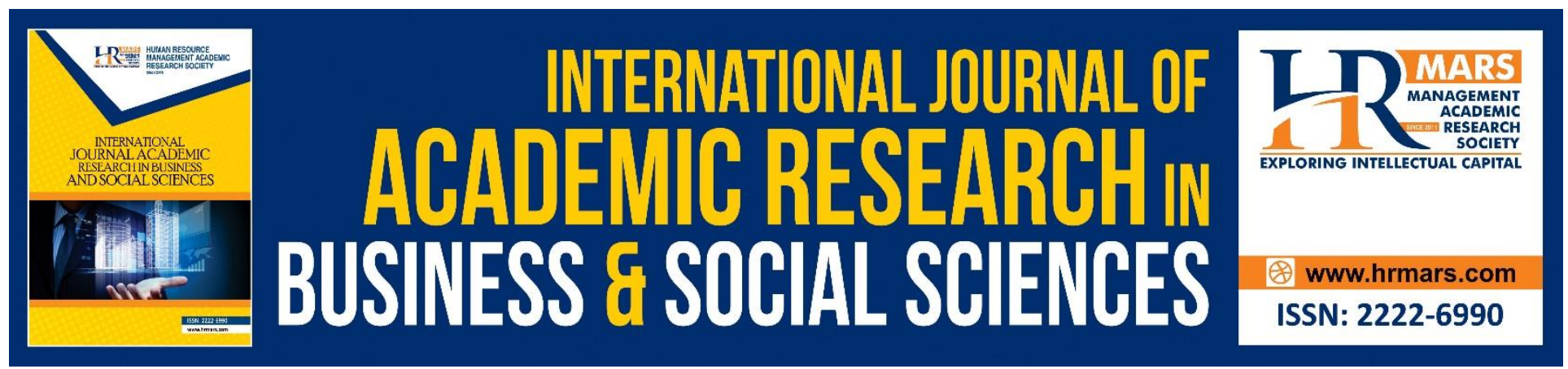

\title{
Artistic Research: Artistic as Research vs Artistic as Method
}

\section{Herry Rizal Djahwasi, Zaharul Lailiddin Saidon}

To Link this Article: http://dx.doi.org/10.6007/IJARBSS/v10-i11/8091
DOI:10.6007/IJARBSS/v10-i11/8091

Received: 03 September 2020, Revised: 30 September 2020, Accepted: 21 October 2020

Published Online: 15 November 2020

In-Text Citation: (Djahwasi, \& Saidon, 2020)

To Cite this Article: Djahwasi, H. R., \& Saidon, Z. L. (2020). Artistic Research: Artistic as Research vs Artistic as Method. International Journal of Academic Research in Business and Social Sciences. 10(11), 292-309.

\section{Copyright: (c) 2020 The Author(s)}

Published by Human Resource Management Academic Research Society (www.hrmars.com)

This article is published under the Creative Commons Attribution (CC BY 4.0) license. Anyone may reproduce, distribute, translate and create derivative works of this article (for both commercial and non-commercial purposes), subject to full attribution to the original publication and authors. The full terms of this license may be seen

at: http://creativecommons.org/licences/by/4.0/legalcode

Vol. 10, No. 11, 2020, Pg. 292 - 309

Full Terms \& Conditions of access and use can be found at http://hrmars.com/index.php/pages/detail/publication-ethics 


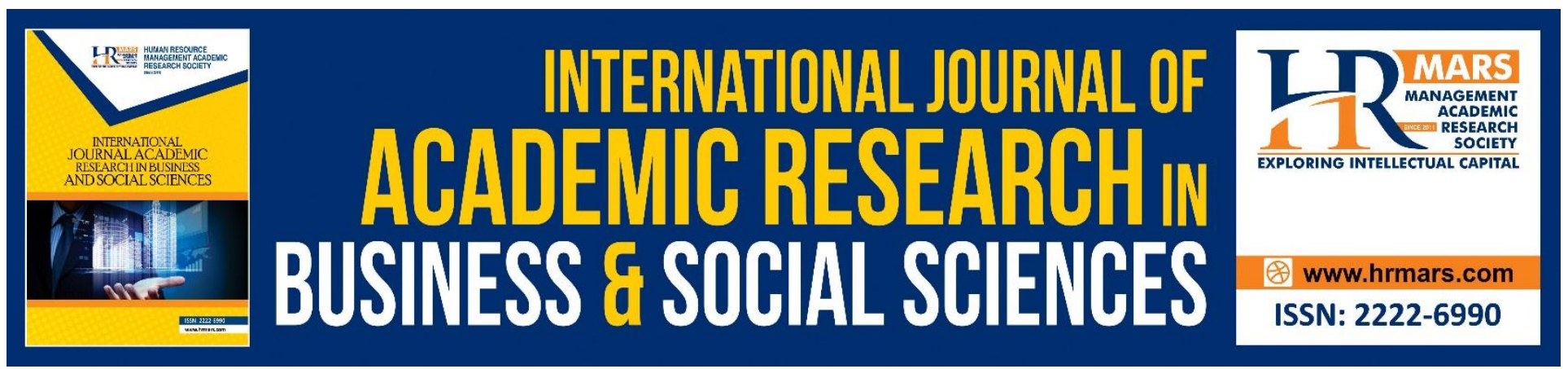

\title{
Artistic Research: Artistic as Research vs Artistic as Method
}

\author{
Herry Rizal Djahwasi, Zaharul Lailiddin Saidon \\ Department of Music and Music Education, Faculty of Music and Performing Arts, Sultan Idris \\ Education University, Malaysia
}

\begin{abstract}
Reflecting on what is currently happening to artistic research in an academic setting, we identified three domains of knowledge that must be interpreted appropriately. In the present article, these three domains of knowledge to which we refer are covered the way we think about art, the way art is processed, and the art works itself. The way we think about art is closely related to the profile of knowledge which is philosophically known as ontology. The way art to be processed is closely related to the structure of knowledge which is philosophically known as epistemology. Meanwhile, the art works itself is closely related to the value of knowledge which is philosophically known as axiology. These three aspects play a role in determining the artistic research paradigms carried out in an academic environment. Based on literature review, we have classified artistic research into two paradigms. The first paradigm, we called artistic as research, in which this notion is representation that artistic works is the production of knowledge. The second paradigm we call artistic as a method, in which this notion is triggered from the understanding that artistic works can be expressed based on research design. Our main motivation to promote two paradigms of the artistic research is to further develop artistic research in conducting scholarly communication. Finally, this article specifically describes how artistic practice and research in academic settings can come together.
\end{abstract}

Keywords: Artistic Research, Artistic Method, Research in Art, Artistic Practice, Artistic as Research, Artistic as Method.

\section{Introduction}

As with other disciplines, the art such as music, dance, theatre, visual art, have become a discipline through gradual and continuous research. This development was driven by the great works of art moving across historical dimensions and occupying various dimensions of space. Sonderen (2017) assert that at least art and scholarship were interwoven more than two hundred years ago around 1800. However, in the Western intellectual tradition, there are different emphases in interpreting theory and practice (Nelson, 2013). It implies that discipline in the art, such art history, art theory and art philosophy have limitations in discussing the process of creating art works. As described by Slager (2004), art itself lost its authority and autonomy. Art history, art theory and art philosophy, was exposed as an ideology. Indeed, the people, in this sense artist, who are involved in the creation of 
INTERNATIONAL JOURNAL OF ACADEMIC RESEARCH IN BUSINESS AND SOCIAL SCIENCES Vol. 10, No. 11, 2020, E-ISSN: 2222-6990 @ 2020 HRMARS

art rarely express their works in the form of theory. Since the creation of art is considered as inherent mysterious activity, which is in some way inaccessible (Newbury, 1996). In addition, the artist doesn't even feel comfortable verbalising his works (Frayling, 1993).

The gap between art disciplines and art works is a gap in scholarly discourse. Since the art discipline is not sourced from the first-hand inquiry. This also confirms that art works has no attempt to express itself scientifically directly. In other words, art works was articulated by translator or maybe interpreter or we call it art researchers. In this regard, Davey (2006, p. 20) emphasizes specifically, that 'the connection between art works and art theory is in considerable need of being rethought, cause the historical relation between these two areas of intellectual endeavour is marked out by a topography of unease'. It is not an exaggeration to interpret the situation as an anomaly between art theory and art works in the scope of art discipline.

In the art discussion, the term of art works is usually spoken as artistic. Broadly speaking, the artistic is similar with concrete form of art works. In academic institutions, art-based research is well known as artistic research. It must be admitted that there is a lack of tradition in artistic research. In this case, Christopher Frayling (1993) describe until the nineteenth century, the artist has difficulty persuading people of the connection of art with research.

The major changes in academic research of art began in the 1970s, and grew rapidly in the 1990s, when artistic research took its place in the field of academic research and associated with a principle of scholarship (Sonderen, 2017; Sinner et al., 2006; Macleod \& Holdridge, 2006; Hannula et al., 2005) which is actively pioneered by the visual arts and design fields (Borgdorff, 2006). Towards the end of the 2000s artistic research became firmly established in universities in the UK, Australia, Canada, Scandinavia, South Africa (Baz Kershaw, 2009). Growing artistic practice in an academic setting gives the role of artists to carry out research based on art practice, in which this model is known as the practitioner--researchers model (Nelson, 2013; Sullivan, 2009; Haseman and Mafe, 2009; Hannula et. al., 2005; Davey, 2006; Barrett, 2007), and specifically Elkins (2009) describes it as "Artists with PhDs". In this understanding Smith and Dean (2009); Sullivan (2009); and Borgdorff (2006) require that artistic research must seek two results, the first is artistic process, and the second is artistic works.

Our observation based on a number of literatures shows that the discussion of artistic research was coloured by the rivalry of the two paradigms. The first paradigm considers artistic practice as research. This paradigm affirm that an artistic t research inquiry is specialist (Elkins, 2009). In this perspective, artistic works is not expressed by the research, but in that expression become the research itself' and 'practice is the principal of research activity' (Haseman 2006, p, 102-103) with 'a very specific sort of knowing (Bolt, 2007, p. 33) to get substantial insights rather than coming to such for definite conclusions as a research answer (Nelson, 2013). Briefly, how the creation of art represents itself as research (Kirkkopelto, 2018). However, this paradigm will face challenges from established research paradigms. Since this paradigm is built on the view that artistic research is a new research species, in which the design and trajectory do not refer to conventional research. We define this paradigm as artistic as research.

The second paradigm considers artistic practice as a method. In this view, artistic research rests on a merging of art and inquiry (Saarnivaara, 2003) in the form of holistic or integrated approach (Hunter 
INTERNATIONAL JOURNAL OF ACADEMIC RESEARCH IN BUSINESS AND SOCIAL SCIENCES Vol. 10, No. 11, 2020, E-ISSN: 2222-6990 @ 2020 HRMARS

et al., 2002). In this paradigm, problem-centre or issue-centre of the research and the problem at the centre of research dictates the methodology (Leavy, 2015; Makela, \& Routarinne, 2006; Biggs \& Büchler, 2007, 2008). The basic tenet of this paradigm is to build a reciprocal relationship between artistic practice and academic research models. We define this paradigm as artistic as method.

The constellation of the two paradigms in the artistic research induce that there are thus far quite few methods which can be considered generally valid and divisible (Nyberg, 2019). However, a number of basic things that should be clarified in the paradigm of artistic as method. Hannula et al., (2005) questioned about what framework should artistic research be carried out? Meanwhile, from the paradigm of artistic as research, Kirkkopelto (2018) questioned about how are artistic research to be distinguished from traditional and institutional modes of art-making? In this connection, we agree as suggested by Slager (2004) that artistic scholarly communication has to be regularly readjusted and reassessed.

In the present article, we will discuss issues pertaining to artistic as a research and artistic as a method within the scope of research in art based on a number of literatures. This article is an attempt to develop and promote artistic research in order to improve scholarly communication and provide a theoretical perspective of artistic research based on two existing paradigms. In other word, the main point we shall address in this paper is to show how artistic research leads them to situated academic research.

\section{Research in Art}

The main reason the idea that the art can be regarded as a form of knowledge have no secure history in contemporary philosophical thought, since viewed the arts as largely emotive rather than primarily informative (Eisner, 2008). Research in art has become a polemic and has been widely discussed in several forums, because it is considered to interfere with the definition of what could be called "academic research tradition". Facing these doubts, Frayling, (1993) reminded, that two aspects are important in determining further development of research in the arts: "the stereotype of scientist as researcher need some adjusting-to make it seem closer to art and design and art investigation needs cognitive explanation rather than expressive idiom."

Christopher Frayling's (1993) influential paper on 'Research in Art and Design' is a widely used reference in classifying art research in academic setting, especially for post graduate program (Borgdorff, 2006). This classification help to frame debates about the character, origin, and appropriateness of research in art disciplines within the academic setting (Macleod and Holdridge, 2006). Frayling's classification are as follows:

1. Research into art and design

This investigative model aims to draw theoretical conclusions about art practice and concentrate on what has been written about art and art-related issues (Sonderen, 2017). The models are innumerable, because each branch of the arts discipline has its own derivatives (Frayling, 1993) and tends to be run by pure academicians. Ideally, pure academicians imply a fundamental separation between the researcher and the object of research. Further explanation of art research and design, Montag (2000, p. 9) adds an explanation that:" "the 
INTERNATIONAL JOURNAL OF ACADEMIC RESEARCH IN BUSINESS AND SOCIAL SCIENCES Vol. 10, No. 11, 2020, E-ISSN: 2222-6990 @ 2020 HRMARS

researcher is not using art to generate knowledge but is using art as a subject about which knowledge is generated" This research model is commonly conducted in established academic disciplines, including musicology, music theory, art history, art theory, media studies, iconographic study, and literature (Borgdorff, 2006).

2. Research through art and design

Broadly speaking, research through art uses art as a medium to implement something else. Borgdorff $(2006,2011)$ affirmed studies in "the service of art practice" and he calls it the 'instrumental perspective'. For instance, a piece of technology to do something no one had considered before and communicating the result (Frayling, 1993)

3. Research for art

Research for art is where the end product is an artefact. The goal is not primarily communicable in the sense of verbal, but in the sense of visual or iconic or imagistic communication (Frayling, 1993) Research for art was the most problematic and the most controversial of the three ideal types (Borgdorff, 2012; Macleod \& Holdridge, 2006). It concerns research that does not assume the separation of subject and object, and does not observe a distance between the researcher and the practice of art (Borgdorff, 2006). There were arts practices, on the one hand, and 'academic' research on the other (Nelson, 2013). In other word, artist intuitively adopts the dual roles of the researcher and the researched (Smith \& Dean, 2009; Sullivan, 2009)

When examined closely, research for art is the origin of artistic research. Since placing the end product is an artefact or artistic works. Even though, there is perspective that artistic research cannot be communicated in a verbal sense needs further clarification. The most important thing is to understand, artistic research is not only about the willingness and ability to do research, but the crucial point is to have adequate competencies as a practitioner, and the knowledge generated by a practitioner process must be pursued explicitly (Hernández, 2013). Implicitly this means that typical research for art is the domain of practitioner-academicians research.

The perspectives of the research and artistic are mutually constitutive but non-reductive artistic processes is spatial-temporal existence. What about John Dewey's "learning-by-doing" is not only an exclusive educational principle but underlies the epistemic point of view of scholarly in general (Westerlund, 2003), when we refer to this thinking, artistic as research is a kind of thinking in action. Various related terms have appeared in the literatures to denote artistic research, in which implicitly associated from the understanding of research for art, such as practice-based research and practice led research (Candy, 2006). Practice led research and research led practice (Smith and Dean, 2009), art-research (Leavy, 2015). Practice-based research is a term predominantly associated with art research. However, this definition refers more to research findings, not research design. The crucial point is related to artistic research to be considered part of academic research as confirmed by Borgdorff (2006) that "the distinctiveness of art research, evinces not only a comparable intimate bond between theory and practice, but also embodies the promise of a distinctive path in a methodological sense that differentiates artistic research from the more mainstream academic research". Biggs \& Büchler (2007) underline that "elements of academic research need to be reframed 
INTERNATIONAL JOURNAL OF ACADEMIC RESEARCH IN BUSINESS AND SOCIAL SCIENCES Vol. 10, No. 11, 2020, E-ISSN: 2222-6990 @ 2020 HRMARS

in such a way as to account for the specificities of design practice, without losing their original purpose".

\section{Artistic as Research}

Our proposal which addresses the paradigm of artistic as research is built on the notion that art can be understood as a process of inquiry and the production of knowledge. In order to promote an argumentation of artistic as a research, we have to look back at what is actually the background of this conception. In this connection, we believe it is important to clarify from the beginning our understanding about the nature of the research and artistic practice itself. Based on a number of literatures. There are three aspects that must be clarified in order to promote artistic as research in an academic setting. First, the presence of formal theory, second, research trajectory or research design and third, research findings. Therefore, we propose my basic arguments should touch upon a fundamental understanding of artistic as research in an academic setting.

The intervention of formal or existing theory becomes a dilemma in artistic practice. The nature of artistic practice is an effort to create or realize artworks, which are affiliated voluntarily with practical law (Gadamer, 1975). In this sense, artistic practice is considered as theoretical practice (Macleod \& Holdridge, 2006; Melville, 2001). Meanwhile in the perspective of conventional research, research is the methodical answering of questions to generate relevant knowledge (Sonderen, 2017) or discovering substantial inside (Nelson, 2013). Conventionally, research questions -as the starting point and primary determinant of the research design (Maxwell, 2013)-are often based on theories that the researcher seeks to test (Creswell, 2009). In other word, the conventional research structure involves conceptual structure formal theory in its logical features (Eisenhart, 1991). From this perspective, the presence of formal or existing theory in conventional research is considered to be at odds with the nature of artistic practice. We took the initiative to illustrate that the paradigm of artistic practice as depicted in Figure 1, while the conventional research paradigm as depicted in Figure 2 
INTERNATIONAL JOURNAL OF ACADEMIC RESEARCH IN BUSINESS AND SOCIAL SCIENCES Vol. 10, No. 11, 2020, E-ISSN: 2222-6990 @ 2020 HRMARS

Figure 1 artistic practice

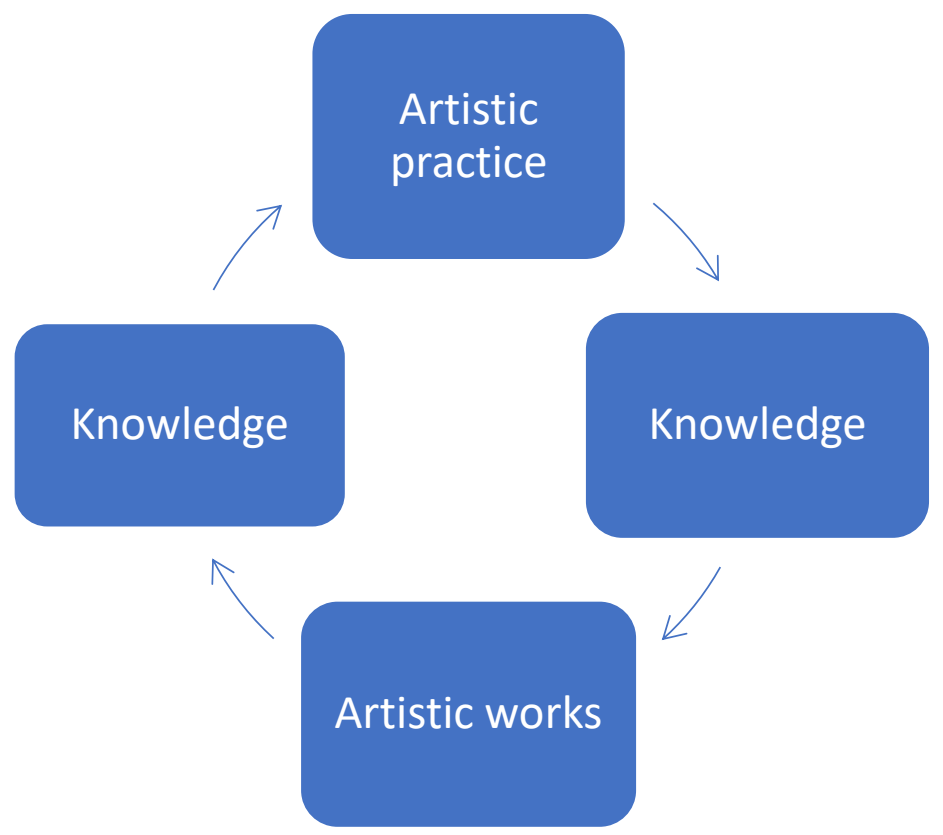

Figure 2 traditional research cycle

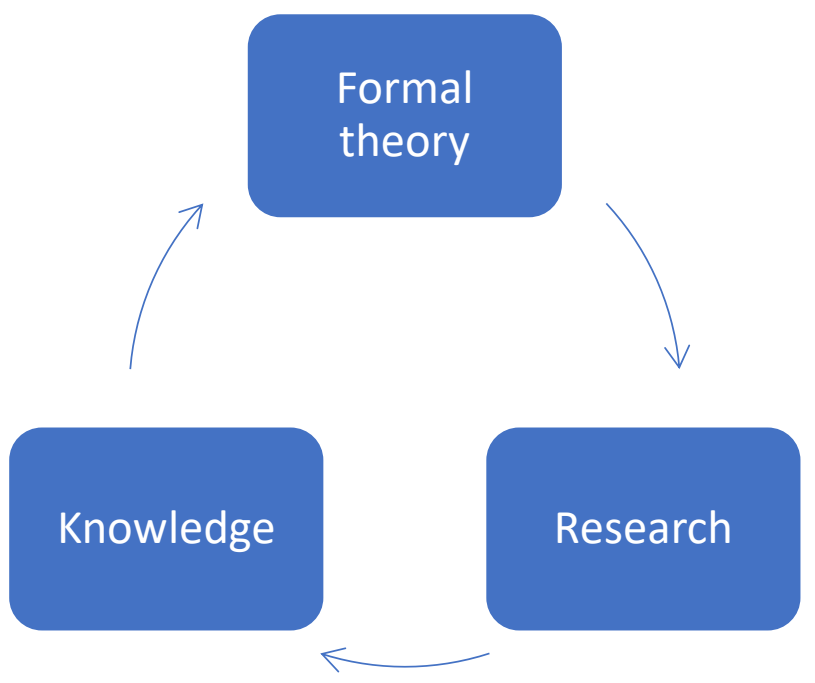

The conclusion that can be drawn based on the understanding above is that artistic practice has strong indication not to be procedurally oriented and does not deal with formal theory at the outset. On contrary, conventional research has to be procedurally oriented and deal with formal theory at the outset of the investigation. This matter is emphasized by Estelle (2007), stating artistic practice is personally situated, interdisciplinary, diverse, emergent approaches in nature, and often contradict what is expected of traditional research.

There are three main arguments regarding the incompatibility of views of the artistic practice with the theoretical approaches in conventional research. First, artist's competence itself have the capacity to explore and explain complex theoretical issues (Nelson, 2013; Sullivan, 2009). Second, 
INTERNATIONAL JOURNAL OF ACADEMIC RESEARCH IN BUSINESS AND SOCIAL SCIENCES Vol. 10, No. 11, 2020, E-ISSN: 2222-6990 @ 2020 HRMARS

formal theoretical intervention is potentially limiting accelerating to its full potential and seek a theoretical practice' or a 'theoretical object (Haseman, 2006). Third, there is no practice that can be fully theorised (Davey, 2006). However, it does not mean that artistic practice cannot be brought into the world of research. There is a need for special methodologies and methods familiar to practitioners (Gray, 1996) with groundwork of human empathic experience (Barone \& Eisner, 2006; Eisner, 2011; Gadamer,1975). In order to label artistic practice as research, we should give attention to something that can be claimed as research in a broader sense.

Each discipline field has particular constellations of questions, methods and procedures. In other word, each discipline provides shared ways of "seeing" the world, of working, of testing each other's beliefs' (Popkewitz, 1984, p. 2-3). Based on this perspective, to claim any research in an academic setting does not only concern with generally understood norms of inquiry or a protocol in the conventional research. The nature of discipline must also be the main reference. In the connection of the art discipline, it is a lameness if artistic practice should concentrate more on being recognized as research than artistic pursuit.

Haseman (2006) in "A Manifesto for Performative Research" argues that there are enough reasons to suspect that a pluralistic artistic research cannot simultaneously be conventional research which is researcher subjectivity stands to infect the objective 'truth'. The typical artistic research disseminates radical dis-location of ways of knowing (Kershaw, 2009). This typical has a distinctive trajectory of inquiry that is best seen in the way that conceptions and constructions of new knowledge are framed (Sullivan, 2009). In this perspective, the role of research in artistic practice is a means rather than an end (Sonderen, 2017).

Before discussing how artistic as research handles conventional research trajectories, it would be helpful to examine how artistic as research is translated as knowledge through explanation in the philosophical background. Related to this matter, Pring (2000, p. 89) stated, 'without the explicit formulation of the philosophical background, researchers may remain innocently unaware of the deeper meaning and commitments of what they say or how they conduct their research'. Philosophically, ontology positions and epistemic stances are a crucial point to choose a methodology which reflect the 'researcher positionality' (Sikes, 2004; Jackson, 2013; Grix, 2001; Crotty, 1998).

Philosophically, ontology positions and epistemic stances have a very strong tendency to place artistic as research as a representation of subjectivisms. Subjectivists establish claims of knowledge rely on interpreting of objects (Grix, 2001; Crotty, 1998), and Perceptually believe (Audi, 1998). Referring to Gilbert Riley's view, artistic as research can be classified as "knowing how" which implies a related meaning to practical skills and is also called procedural knowledge. Barbara Estelle, (2007) cited Martin Heidegger's notion of "praxical knowledge" or what theorised as the material basis of knowledge, Baumgarten's terms, sensate knowledge and Gadamer (1975) illustrated it as local knowledge. Finally, referring to Creswell's (2002) definition, artistic as research can be categorized as Pragmatic Knowledge, which implies to locate claims of knowledge arise out of actions, situations, and consequences rather than antecedent conditions, in order to facilitate individual researchers to have a freedom of choice of methodology, in which place truth is what works at the time.

In many other discussions of knowledge framed in conventional research, research questions are appointed as substantial component (Miles \& Huberman, 1994; Robson, 2011; Rudestam \& Newton, 2007; Maxwell, 2013). In conventional research, a research question to be set at the outset. In particular, Ravitch and Riggan, (2017) emphasize that research questions are related to how 
individuals construct knowledge or commonly known as the epistemological assumption. Yet artistic researchers do not initiate research projects with a sense of 'the problem, they are led by what is best expressed as 'enthusiasm for practice' (Hasemen,2006). Due to their works are more intuitive for providing substantial insights rather than such definite conclusions as to constitute 'answers (Nelson, 2013) and seemed more like a series of interim conclusions, as answers to questions which is depending on the artist's disposition (Sonderen, 2017). In addition, it has to do with something about the ethical foundation and personal choices of the artist (Kirkkopelto, 2018).

It is worth noting, a number of the terminology mention above such as 'enthusiasm for practice' (Hasemen, 2006), intuition (Nelson, 2013) and the artist's disposition (Sonderen, 2017) rather symbolizes a personal perspective. According to Kemp, (1964) a personal perspective in art area is a representation of artistic intention. However, the artistic intention is neither available nor desirable as a standard for judging the success of artistic work (Wimsatt \& Beardsley, 1946), since the relationship between the artistic intention and the physical manifestation of their artistic work is highly contested and always with some trepidation (Wharton, 2015).

The trepidation is quite plausible when it comes to the question, whether artistic intention is worthy enough to be judged as a frame of knowledge in academic research. Responding to this question, we think it is difficult to find references to answer, because there are no sufficient methods to assess artistic intentions or an artist's mind in the scope of academic research without involving scholarly context. Related to this Borgdorff (2006) has interesting view that can be accounted for, that not all artistic practice is considered as research and which criteria must be satisfied if artistic research to be defined as academic research?

To be defined as academic research, the concept of artistic intention itself must resonate in a scholarly context. Without a scholarly context- we need to emphasize once again-, artistic intention will encounter problem in meeting the criterion-referenced assessment in an academic setting. Scholarly context itself in the terms of research is commonly mentioned as the significant of study or contribution of knowledge. Kalvemark (2011, p. 16) quotes from "The Norwegian model" which is very worthy of consideration. Truly, artistic research should accommodate personal professional perspective and significant for study in the form of how the project contributes to professional development of the subject area or other disciplines. Forward, the consideration of the "Norwegian Model" will bring greater awareness of possible benefits in the relationship between artistic practice and academic research. This model encourages both parties have everything to gain from a mutual exchange (Karlsson, 2007, p. 166) based on the passions and interests of hands-on artistic researchers (Kershaw et.all.2011).

The discussion of methodology in conventional research normally include three aspects: the phase of investigation, typical methodology, and research methods. In conventional research, methodology is the profiling of knowledge that uses a theoretical lens to implement practice (Rust, C., Mottram, J, \& Till. J, 2007; Newton, 2007; Maxwell, 2013). However, this matter is opposed to the artistic research paradigm where transformative procedures uses a practical lens. In other word, formulating the phase of investigation is not possible as far as the artistic process has not been carried out. The main reason, artistic processes as a part of artistic production is not some a kind of formula or recipe (Sonderen, 2017). Artistic research is an alternative model of inquiry (Eisener, 1997) by applying a 


\section{INTERNATIONAL JOURNAL OF ACADEMIC RESEARCH IN BUSINESS AND SOCIAL SCIENCES}

Vol. 10, No. 11, 2020, E-ISSN: 2222-6990 @ 2020 HRMARS

performative methodology as a third research paradigm. This Paradigm is different from qualitative and quantitative approaches (Hasemen, 2006; Sonderen, 2017) which uses practical artistic or creative processes as research methods (Kershaw et. al., 2011). The presence of theory in this model is ultimately the result of artistic practice rather than vice versa (Estelle, 2007). in other words, "materialising practices" stems from an ongoing performative engagement and productivity (Bolt, 2004).

Close examination of the above, led us to conclude that there are sufficient reasons to place methodology in artistic as research not just as part of presenting of knowledge but is considered the research findings. The placement of the methodology as part of the research findings clearly contradicts the conservative research paradigms. In artistic as research paradigm, these are three main arguments to consider the methodology as research findings. First, the methodology must be aligned with contexts of artistic production (Estelle, 2007). Second, methodology is submitted as substantial evidence of a research inquiry (Nelson, 2013). Third, methodology includes critical reflection and reflexive action as the methods (Sullivan, 2009). These three arguments understand us, that the way art is processed and the work of art itself are the research findings. We propose to illustrate the paradigm of artistic as research as depicted in Figure 3

Figure 3 show a framework of artistic as research

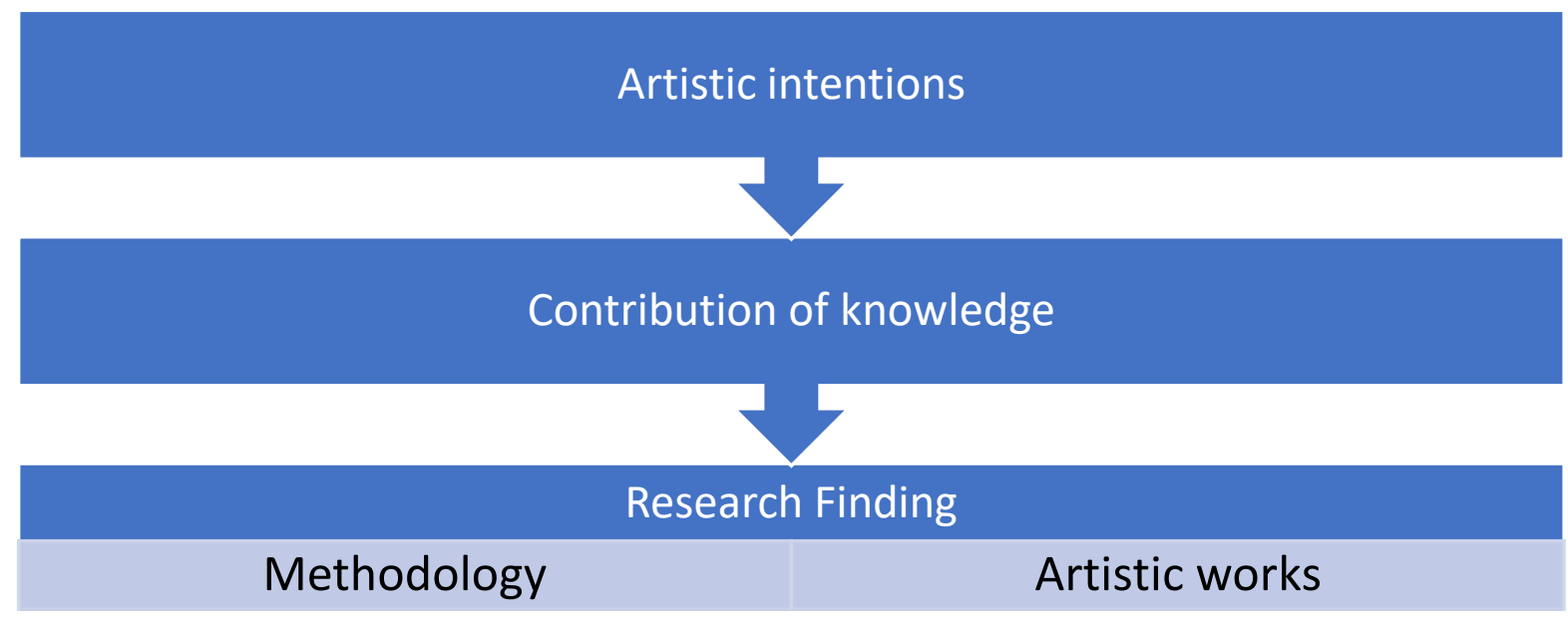

The existence of a methodology as research findings in artistic as research produces a clear point for the difference between an artist as a practitioner and an artist as a researcher. In artistic as research, the methodology is considered as the way art is processed. Artist as a practitioner such as Beethoven and Leonardo da Vinci are the great artists who in many of their works imparts artistic knowledge through their works. However, they did not disseminate the process of his work. This bring us to conclude that Beethoven and da Vinci are great artists but they are not art researchers.

\section{Artistic as Method}

The emergence of presumption that there is lack of scholarly communication in artistic research is something that must be responded positively. This assumption is based on the general view that the scholarly concept of art itself cannot be understood generally, and the development of knowledge is 
INTERNATIONAL JOURNAL OF ACADEMIC RESEARCH IN BUSINESS AND SOCIAL SCIENCES Vol. 10, No. 11, 2020, E-ISSN: 2222-6990 @ 2020 HRMARS

more individualistic or very exclusive. In addition, art is sometimes believed to speak for itself (Hanula et.all. 2014). In order to accommodate artistic practice in a scholarly context, the existence of artistic practice must have a role in communicating the intellectual conditions of artistic production (Slager, 2004). The notion of artistic research for establishing scholarly communication is motivated by a desire to ensure equitability between artistic practice and academic research (Biggs, 2007; Rust, 2007, Makela et. al., 2011). This notion gives rise to an equal partnership between artistic practice and research (Nimkulrat, 2009).

As discussed earlier, the paradigm of artistic as research placing the presence of methodology as well as artistic works as part of research finding. However, artistic as a method has a different approach with the paradigm of artistic as research. The notion of artistic as method is most straightforward way to obtain an artistic works using framework of research as it has been known. Nevertheless, this does not mean that artistic as a method is carried out with the same perspective as conventional research. Since the researcher and the researched are the same person it is not known from the perspective of traditional research. In addition, the personal perspective which is characteristic of artistic research cannot be ignored.

Our notion to classify artistic as a method based on the basic conception that the artistic process can be assumed as a method or research instrument. In order to understand this conception, there is needs to stress the distinction between methodology and method prior to the discussion. Although in general the basic understanding of methodology and method in both traditional research and artistic research has the same conception. In many cases, the terms methodology and method are interpreted in the same way. By emphasizing the distinction, we will obtain a conception in which artistic practice is placed and defined in artistic as method with a specific methods and forms of representation.

The basic conception of methodology is general strategy or a broader conception related to research design which includes data collection techniques or methods in it (Miles \& Huberman, 1994; Bridges and Smith, 2006; Ruitenberg, 2009; Clingan, 2008; Creswell, 2009; Maxwell, 2013, Jackson, 2013). In short, methodology concerns research procedures, while methods concern practical procedures. Generally, in the research paper, methodology and method are discussed in the same chapter or more precisely the research method is part of the methodology. The main question, is it possible to determine research procedures (methodology) at the outset without involving practice procedures (method)? The answer depends on the atmosphere constructed by the research question, since the principle of methodology and method are based on the research question guidelines (Miles and Huberman, 1984; Creswell, 2009; Maxwell, 2013; Jackson, 2013; Howell 2013). This notion encourages us to draw a conclusion, that the scenario of artistic as a method can only be implemented with a research question agenda. In other word, artistic process and artistic works are to be presented as part of the answer to research questions (Biggs, 2002) in order "to give a voice to the artefact" (Makela, 2007, p. 163).

The presence of research questions in artistic research is not something prohibition for some academic. Biggs and Buchler, (2007) stated the absence of a question and answer in artistic research as an indicator of professional practice rather than research. The absence of a question will result in 
INTERNATIONAL JOURNAL OF ACADEMIC RESEARCH IN BUSINESS AND SOCIAL SCIENCES Vol. 10, No. 11, 2020, E-ISSN: 2222-6990 @ 2020 HRMARS

the artist not having a clear direction and unable to clearly articulate the artistic practice (Makela et. al. 2011). The research question will map the theoretical side of the conceptual world and the world of experience as an artist. Indeed, the perspective of artistic practice cannot determine beforehand (Slager, 2004). Practice is a principle of artistic research, and text in words does not facilitate to situations of artistic origin (Haseman, 2006; Gale and Featherstone, 2011). But the research questions in artistic research is to provide a taking into account the evolutionary nature of artistic production and more adequately considering for the topical process of artistic communication. This view is in line with what Hanula et.all. $(2014 ; 28)$ who stated that artistic research consists of a combination of art-making and word-making-both sides are needed.

Philosophically, the tendency to combine theory and practice is a hallmark of constructivist thinking. Constructivist thinking is a representation of artistic research, which in some ways tends to synergize with general academic views due to constructivists which make it possible to build meaning with externalization and internalization (McNiff and Whitehead, 2002). According to Maggi Savin-Baden and Katherine Wimpenny, (2014, p. 3):

"Constructivists doing research seek to understand the way meanings are constructed and to capture how such meanings are presented and used through language and action. They use a range of approaches to seek individuals' reconstructions of their realities."

However, it should be understood that in order to implement the idea of constructivism in artistic research, a researcher must have a mature view both from the research side and the artistic side. The existence of theory here is not mean to dictate artistic practice, since the artistic practice is not destined to remain the same (Davey, 2014). Theory description is more to encourage the emergence of a critical context in both artistic processes and artistic production in order to obtain and overview of what actually the content is of the research artists conduct (Slager, 2004). Critical contexts affect the way the artistic works is interpreted (Biggs 2002: 20-23). However, Critical contexts do not mean identifying gaps, since the artwork doesn't identify gaps (Gale and Featherstone, 2011). According to Davis (2004: 204) 'sometimes gaps left unfilled', arts will 'tell us more as "empty" spaces than "full" re/contextualised ones' (Davi,s 2004: 204). Critical contexts will unpack the element of artistic which is illustrated by Merleau-Ponty's as an attempt to see what others leave unnoticed, and think differently about art practice, so that many of its hidden assumptions can be recovered (Davey, 2014).

Critical contexts, as a formulation of the problem statement - research questions, will promote methodology and methods in two different dimensions. This is shown by unpacking the element of artistic to become theoretical side (methodology) and practical side (method). The dimension of methodology in artistic as a method is referred more to research design. According to Friedman, (2003, p. 507-508) "most definitions of design share three attributes. First, the word design refers to a process. Second, the process is goal orientated. Third, the goal of design is solving problems, meeting needs, improving situations, or creating something new or useful. Both Dimension in the conception of methodology and method is an effort to account for the specificities of design practice in artistic research, without losing their original purpose.

Needs to be stress here, method in artistic as method, is not understood to design activities or research instruments as they are known in conventional research. The role of method in artistic as method is a means to achieve the purpose of research or more concretely, arguing the artistic 
processes and artistic works can be understood as an answer to the research questions. In other word, in artistic as method, method is considered as research finding. There are three reasons for placing method as the research finding. First, artistic area as well as art activity must be understood as authentic participation. Second, data characteristics in artistic practice comes from data-creation not data collection. Third, data-creation (artistic process) will just end when artistic production is completed. This is the reason that the method is the last variable to be determined in artistic research process (Biggs, 2004, p. 12-19).

The Paradigm of artistic as method enables a more accountable reporting system, which emphasis equally placed on theory and practice as well as the reflection and documentation of practice (Makela \& Nimkulrat, 2011; Nimkulrat, 2009, p.37). The criterion-referred assessment on artistic as method reflects the assessment based on the assessment criteria established by the researcher, such as:

1. Sets his/her learning goals

2. identifies and develops learning strategies to achieve such goals;

3. Develops his/her learning, which includes identifying problem areas and means of addressing these problems;

4. Identifies and selects relevant resources and the necessary support;

5. Assesses his/her own progress and defines his/her own criteria for evaluating performance and learning (including strategies, materials, etc.).

We propose to illustrate the paradigm of artistic as method as depicted in Figure 4

Figure 4 a framework of artistic as method

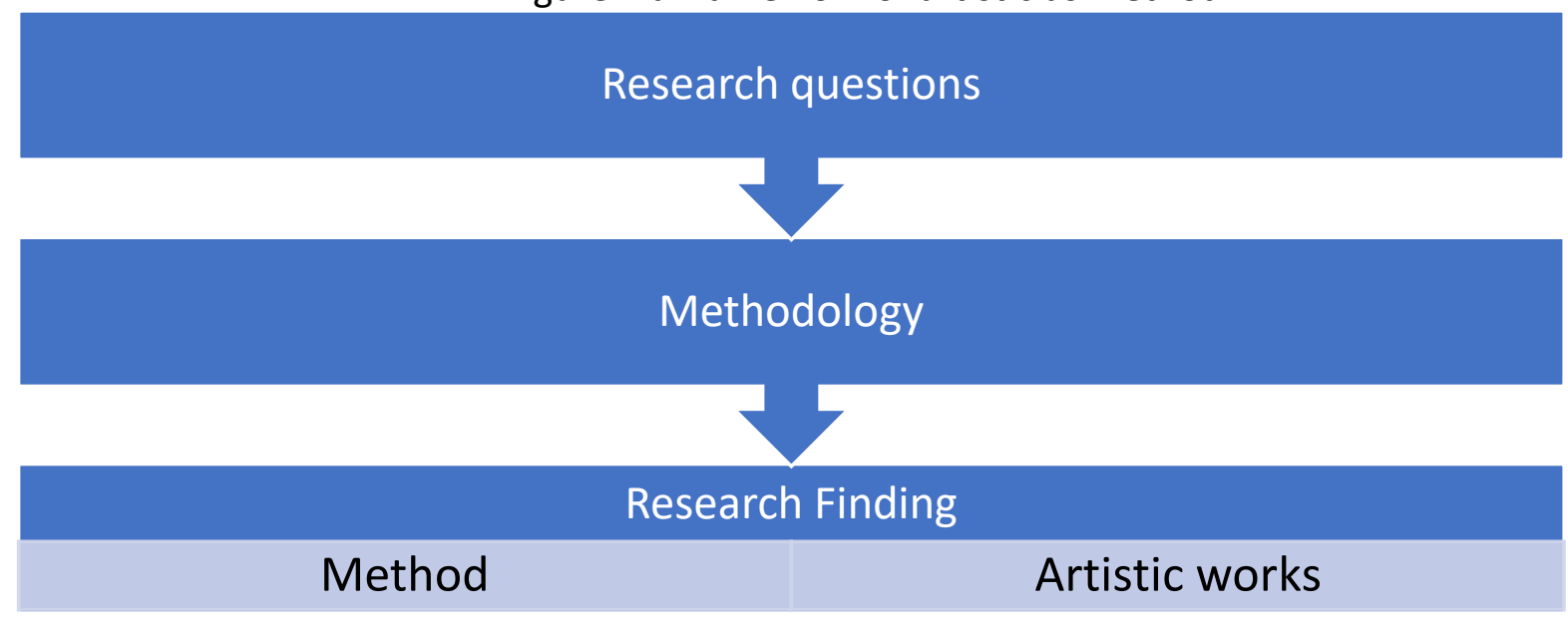

Artistic as research is to express artistic practice, where research strategy (methodology) is carried out through practice. Meanwhile, artistic as method which reveals the context of artistic practice, where research strategy (methodology) is carried out by providing context of practice (method). In the paradigm of artistic as method, method as well as artistic works is part of research findings. 
INTERNATIONAL JOURNAL OF ACADEMIC RESEARCH IN BUSINESS AND SOCIAL SCIENCES Vol. 10, No. 11, 2020, E-ISSN: 2222-6990 @ 2020 HRMARS

\section{Conclusion}

Even there is no single format for artistic research, this article at least contributes to build an understanding of how art and academic research work together without losing its original purpose. The theoretical contribution of this article is not to describe artistic theories, but rather to explain how to express artistic practice in scholarly discourse. This article is an attempt to develop and promote artistic research in order to improve scholarly communication and provide a theoretical perspective of artistic research.

What is understood as the artistic domain and how to apply it in academic research is always an ongoing question. It is undeniable that in order to gain scholarly recognition, artistic research is always overshadowed by a scientific approach. Reflect to this matter, it is important to not lose sight of a key element of artistic in conducting of artistic research. In other word, the nature of art discipline should also be the main consideration in conducting artistic research.

The two paradigms we propose for artistic research represent two conceptions in doing artistic research. More or less, these two paradigms dominate conceptions in artistic research. In artistic as research, artistic works can be understood as an implementation of the contextualizing of artistic intention. Meanwhile, in artistic as method, the artistic processes and artistic works can be understood as an answer to the research questions.

We believe that the paradigm classification we offer, artistic as research and artistic as method, will contribute to the understanding of practitioners-academic and undergraduate-post graduate students in carrying out artistic research. Finally, we hope that this article will inspire other scholarly article to improve the development of artistic research.

\section{Corresponding Author}

Herry Rizal Djahwasi

Department of Performing Arts Faculty of Music and Performing Arts Sultan Idris Education University 35900, Tanjung Malim, Perak, Malaysia

Email: herry@fmsp.upsi.edu.my

\section{References}

Audi, R. (1998). Epistemology: a contemporary introduction to the theory of Knowledge, Routledge. Barone, T., \& Eisner, E. W. (2012). Arts-based research. Thousand Oaks, CA: Sage.

Biggs, M., \& Buchler, D. (2007). Rigor and Practice-based Research. Design Issues, 23(3), 62-69. Retrieved August 15, 2020, from www.jstor.org/stable/25224118

Biggs, M., and Buchler, D. (2008). Eight criteria for practice-based research in the creative and cultural industries. Art, Design and Communication in Higher Education, Volume 7, Number 1, pp. 5-18(14) https://doi.org/10.1386/adch.7.1.5_1

Biggs, M., and Karlsson, K. (2011). The Routledge Companion to Research in the Arts, Routledge Birks, M., \& Mills, J. (2011): Grounded Theory. A Practical Guide. London: Sage Publications. Bolt, B. (2007), 'The magic is in handling', in E. Barrett and B. Bolt (eds), Practice as Research: Approaches to Creative Arts Enquiry, London and New York: I. B. Tauris, pp. 27-34.

Borgdorff, H. (2006). The debate on research in the arts. Sensuous Knowledge, Bergen: Bergen National Academy of the Arts, (02). 
INTERNATIONAL JOURNAL OF ACADEMIC RESEARCH IN BUSINESS AND SOCIAL SCIENCES Vol. 10, No. 11, 2020, E-ISSN: 2222-6990 @ 2020 HRMARS

Borgdorff, H. (2009). 'Artistic Research within the Fields of Science', Sensuous Knowledge Publications 6/2009. Bergen Academy of Arts; http://sensuous knowledge.org/publications/62009- artistic- research- within- the- fields- ofscience/.

Borgdorff, H. (2012). The Conflict of the Faculties: Perspectives on Artistic Research and Academia. Leiden University Press.

Bridges, D. (2017). Philosophy in Educational Research: Epistemology, Ethics, Politics and Quality. Springer International Publishing AG

Bridges, D., \& Smith, R. (2006). Philosophy, Methodology and Educational Research: Introduction. Journal of Philosophy of Education, 40(2), 131-135.

Clingan, J. (2008): An Understanding of Textual/Theoretical Research. http://www.prescott. Edu/faculty staff/faculty/jclingan/documents/RMT

Creswell, J. W. (2009). Research Design: Qualitative, Quantitative, and Mixed Methods Approaches (3nd Edition), SAGE Publications, Inc.

Crotty, M. (1998). The Foundations of Social Research: Meaning and Perspective in The Research Process, SAGE Publications Ltd.

Davis, T. C. (2004). 'The context problem', Theatre Survey, 45 (2), 203-9.

Davey, N. (2006). Art and theoria. In Macleod, K. and Holdridge, L (eds), Thinking Through Art: Reflections on art as research. Routledge, 20-39

Elkins, J. (ed.) (2009). Artists with PhDs: On the new Doctoral Degree in StudioArt. Washington, DC: New Academia Publishing.

Eisner, E. W. (1997). The promise and perils of alternative forms of data representation. Educational Researcher, 26(6), 4-10.

Eisner, E. (2008). Art and Knowledge. In Knowles, J. G. and. Cole. A. L (eds). Handbook of the arts in qualitative research: Perspectives, methodologies Sage Publications 3-12

Frayling, C. (1993). 'Research in Art and Design', Royal College of Art Research Papers Series 1(1). London: Royal College of Arts.

Friedman, K. (2003). Theory Construction in Design Research: Criteria: Approaches, and Methods, Design Studies, 24(6): 507-522.

Friedman, K. (2017). Research Writing Workshop. Politecnico di Milano, Italy. https://www.academia.edu/2953871/Friedman._2017._Research_Writing_Workshop -

Gadamer, Hans-Georg. (1960). Truth and Method, tr. Weinsheimer, J. and Marshall, D.G. London: Sheed \& Ward

Gray, C. (1996), Inquiry through Practice: Developing Appropriate Research Strategies (cited 18 March 2003), available at: http://www2.rgu.ac.uk/criad/cgpapers/ngnm/ngnm.htm

Gray, D. E. (2014). Doing research in the real world (Third edition). Los Angeles SAGE.

Grix, J. (2001). Demystifying postgraduate research: From MA to PhD. Edgbaston: University of Birmingham Press.

Hannula, M. J., Suoranta, and Vaden, T. (2005). Artistic Research: theories, methods and practices, Gothenburg, Sweden: Academy of Fine Arts Helsinki, and Gothenburg University.

Hannula, M. J., Suoranta, and Vadén, T (2014). Artistic Research Methodology- Narrative, Power and the Public, Peter Lang.

Habermas, Jurgen. (1973). Legitimation Crisis, tr. McCarthy, T. from Legitimation sprobleme im Spatkapitalismus. London: Heinemann Educational.

Haseman, B. (2006) 'A Manifesto for Performative Research', Media International Australia 
INTERNATIONAL JOURNAL OF ACADEMIC RESEARCH IN BUSINESS AND SOCIAL SCIENCES Vol. 10, No. 11, 2020, E-ISSN: 2222-6990 @ 2020 HRMARS

Incorporating Culture and Policy 118: Special issue 'Practice-led Research' 98-106

Haseman, B., and Mafe, D. (2009). 'Acquiring Know- How: Research Training for Practice- Led Researchers', in H. Smith and R. Dean (eds), Practice- Led Research, Research- Led Practice in the Creative Arts (Research Methods for the Arts and Humanities). Edinburgh University Press, 211-281.

Heidegger, Martin. (1954). What Is Called Thinking? tr. Gray, J.G. and Wieck, F.D. London: HarperCollins.

Howell, K. E. (2013). An Introduction to the Philosophy of Methodology. Sage Publications Ltd Hunter, A., Lusardi, P., Zucker, D., Jacelon, C., \& Chandler, G. (2002). Making meaning: The creative component in qualitative research. Qualitative Health Research Journal, 12(3), 388-398.

Jackson, E. (2013). Choosing a Methodology: Philosophical Underpinning, Practitioner Research in Higher Education Journal, 7(1), 49-62. Available at: http://194.81.189.19/ojs/index.php/prhe (Accessed 15 October 2013).

Kalvemark, T. (2011). University Politics and Practice-based Research. In Biggs, M and Karlsson, K. (eds), The Routledge Companion to Research in the Arts, Routledge, 3-23

Karlsson, H. (ed.) (2007) Kontext - Kvalitet - Kontinuitet. Utvardering av Vetenskapsrådets anslag till konstnarlig forskning och utveckling 2001-2005, Stockholm: Vetenskapsrådet

Kiljunen, S., and Hannula, M. (ed.) (2002) Artistic Research. Helsinki: Finnish Academy of Fine Arts.

Kiljunen, S., and Hannula, M. (eds) (2012) 'Inventions and Institutions: Artistic Research as a Medium of Change', presentation at the seminar of the Finnish Society for Aesthetics, 1 March 2012 (manuscript).

Kirkkopelto, E. (2018). Abandoning Art in the Name of Art: Transpositional Logic in Artistic Research. In Schwab M. (Ed.), Transpositions: Aesthetico-Epistemic Operators in Artistic Research (pp. 33-40). Leuven (Belgium): Leuven University Press. Retrieved August 16, 2020, from www.jstor.org/stable/j.ctv4s7k96.5

Kemp, J. (1964). The work of art and the artist's intention. The British Journal of Aesthetics, Volume 4, Issue 2, April 1964, Pages 146-154, https://doi.org/10.1093/bjaesthetics/4.2.146

Kershaw, B. (2009) 'Practice as Research Through Performance', in H. Smith and R. Dean (eds) Practice- Led Research, Research- Led Practice in the Creative Arts (Research Methods for the Arts and Humanities). Edinburgh University Press, pp. 63-75.

Kershaw, B., Miller, L., Whalley, J., Rosemary, L., and Pollard, N. (2011). Practice as Research: Transdisciplinary Innovation in Action, In Kershaw, B and Nicholson, H. (eds), Research Methods in Theatre and Performance, editor, Research Methods in Theatre and Performance, University Press, 63-85.

Leavy, P. (2009) Method Meets Art. New York: Guilford Press.

Maarit, M., Nimkulrat, N., Dash, D. P., Nsenga, Francois-X. (2011). On Reflecting and Making in Artistic Research. Journal of Research Practice Volume 7 (1), 1-12

Maggie, B. G., and Featherston, A. (2011). The Imperative of the Archive: Creative Archive Research, In Kershaw, B and Nicholson, H. (ed.), Research Methods in Theatre and Performance, editor, Research Methods in Theatre and Performance, University Press, 17-40.

Makela, M. (2007). Knowing through making: The role of the artefact in practice-led research. Knowledge, Technology \& Policy, 20(3), 157-163. 
INTERNATIONAL JOURNAL OF ACADEMIC RESEARCH IN BUSINESS AND SOCIAL SCIENCES

Vol. 10, No. 11, 2020, E-ISSN: 2222-6990 @ 2020 HRMARS

Makela, M. (2009). The place and the product(s) of making in practice-led research. In N. Nimkulrat

\& T. O'Riley (Eds.) Reflections and connections: On the relationship between production and academic research (pp. 29-37). University of Art and Design Helsinki, Finland.

Makela, M., \& Nimkulrat, N. (2011, May). Reflection and documentation in practice-led design research. Paper presented at the Making Design Matter conference, Helsinki, Finland, May 29-31. Retrieved December 3, 2011, from http://ocs.sfu.ca/nordes/index.php/nordes/2011/paper/view/375

Makela, M., and Routarinne, S. (2006b). 'Connecting different practices', in M. Makela and S. Routarinne (eds), The Art of Research: Practice in Research of Art and Design, Helsinki: University of Art and Design Helsinki, pp. 10-39.

Marshall, C., \& Rossman, G. B. (2011). Designing qualitative research (5th ed.). Thousand Oaks, CA: SAGE Publications.

Maxwell, J. A. (2013) Qualitative Research Design. SAGE Publications, Inc.

Macleod, K., and Holdridge, L. (2006) (eds), Thinking Through Art: Reflections on art as research. Routledge.

McKenzie, J., Roms, H., and Wee, C. J. W. L. (ed.) (2010) Contesting Performance: Global Sites of Research. Basingstoke: Palgrave Macmillan.

McNiff, J., and Whitehead, J. (2002). Action Research: Principles and Practice. The Taylor \& Francis e-Library

Melrose, S. (2006). "The Body" in Question: Expert Performance- Making in the University and the Problem of Spectatorship"; http://www.eis.mdx.ac.uk/staffpages/satinder/Melroseseminar6April.pdf.

Miles, M. B., \& Huberman, A. M. (1994). Qualitative data analysis: An expanded source book (2nd ed.). Newbury Park, CA: Sage.

Montag, D. (2000) Bioglyphs: Generating images in collaboration with nature's events, PhD thesis, University of Hetfordshire. Online version: www.website.com.Rane.falmouth.ac.uk/pdfs/biogliphs/chap 1

Neilsen, L. (2004). Aesthetics and knowing: Ephemeral principles for a groundless theory. In A. L. Cole, L. Neilsen, J. G. Knowles, \& T. C. Luciani (Eds.), Provoked by art: Theorizing artsinformed research Halifax, Nova Scotia, Canada: Backalong Books, 44-49.

Nelson, R. (2013). Practice as Research in the Arts: Principles, Protocols, Pedagogies, Resistances Palgrave Macmillan.

Newbury, D. (1996) Viewpoint: Knowledge and Research in art and design. In Design Studies 17, 1996, pp 215-219

Nyberg, F. (2019) The Writing and the Doing-about Artistic Research through a Writing Practice in Artistic Research and Literature, in Caduff, C. and Tan Walchli (ed), Artistic Research and Literature Brill, Wilhelm Fink.

Polanyi, M. (1983). The Tacit Dimension. Gloucester, MA: Peter Smith.

Popkewitz, T. S. (1984). Paradigm and ideology in educational research: The social functions of the intellectual. London/New York: Falmer.

Pring, R. (2000) Philosophy of Educational Research. London: Continuum.

Ravitch, S. M., and Riggan, M. (2017). Reason \& Rigor: How Conceptual Frameworks Guide Research. SAGE Publications, Inc. 
INTERNATIONAL JOURNAL OF ACADEMIC RESEARCH IN BUSINESS AND SOCIAL SCIENCES Vol. 10, No. 11, 2020, E-ISSN: 2222-6990 @ 2020 HRMARS

Ruitenberg, C. (2009): Introduction: The Question of Method in Philosophy of Education. Journal of Philosophy of Education, 43(3), 315-323.

Rust, C. (2007). Unstated contributions: How artistic inquiry can inform interdisciplinary research. International Journal of Design, 1(3), 69-76.

Rust, C., Mottam, J., \& Till, J. (2007). AHRC research review: Practice-led research in art, design and architecture. Retrieved December 3, 2011, from http://www.ahrc.ac.uk/about/policy/documents/practice-led_review_nov07.pdf

Saarnivaara, M. (2003). Art as inquiry: The autopsy of an [art] experience. Qualitative Inquiry, 9(4), 580-602.

Savin-Baden, M., and Wimpenny, K. (2014). A Practical Guide to Arts-related Research. Sense Publishers.

Sikes, P. (2004). Chapter 2 Methodology Procedures and Ethical Concerns, in Opie, C. (ed.). (2004). Doing Educational Research. London: Sage

Skains, R. L. (2018). Creative Practice as Research: Discourse on Methodology, Media Practice and Education, 19 (1), 82-97, DOI: 10.1080/14682753.2017.1362175

Schön, D. (1995). The reflective practitioner: How professionals think in action. London: Ashgate/Arena. (First published by Basic Books, New York, in 1983)

Smith, H., and Dean, R. T. (2009). Introduction: Practice-led Research, Research-led Practice Towards the Iterative Cyclic Web. In Smith, H. and Dean, R.T (ed.), Practice-Led Research, Research- Led Practice in the Creative Arts (Research Methods for the Arts and Humanities). Edinburgh University Press, 1-40.

Smith, J., and Small, R. (2017). Is It Necessary to Articulate a Research Methodology When Reporting on Theoretical Research? Current Business and Economics Driven Discourse and Education: Perspectives from Around the World BCES. Conference Books, Volume 15, 202208

Slager, H. (2004). In DISCOURS DE LA MÉTHODE in Annette W. Balkema, A.W. and Slager, H. (eds), Artistic Research. Rodopi B.V, 34-38.

Sonderen, P. C. (2017). Of Research, Passion, and Art. The Journal of Aesthetic Education, 51(1), 5468. doi:10.5406/jaesteduc.51.1.0054.

Sullivan, G. (2006b), Artefacts as Evidence within Changing Contexts (cited 16 august 2020), available at: http://www.herts.ac.uk/artdes/research/ papers/wpades/vol4/gsfull.html.

Sullivan, Graeme. (2006). 'Research Acts in Research Practice', Studies in Art Education, 48 (1), 1935.

Sullivan, G. (2009), Making Space: The Purpose and Place of Practice-led Research, In Smith, H. and Dean, R.T (eds), Practice- Led Research, Research- Led Practice in the Creative Arts (Research Methods for the Arts and Humanities). Edinburgh University Press, 41-65.

Wharton, G. (2015). Artist intention and the conservation of contemporary art. AIC Objects Specialty Group Postprints, Vol. 22, 1-12.

Westerlund, H. (2003). Reconsidering aesthetic experience in praxial music education. Philosophy of music education review, 11 (1), 45-62, published by Indiana university press.

Wilson, E., and Stutchbury, K. (2009). Chapter 4 - Research Design and Ethics, in Wilson, (eds). School Based Research A Guide For Education Students. London: Sage.

Wimsatt, Jr., W. K., and Beardsley, M.C. (1946). The intentional fallacy. Sewanee Review 54 (3): 468-488. 